\title{
PENGARUH EKSTRAK RUMPUT LAUT (EUCHEMA SP.) TERHADAP HISTOLOGI SEL B PANKREAS PADA RATTUS NOVERGICUS GALUR WISTAR DENGAN DIABETES MELLITUS YANG DI INJEKSI ALOKSAN
}

\author{
KURNIATI MAYA SARI, WD \\ Pengajar Akper YPTK Solok
}

\begin{abstract}
Metabolic diseases such as diabetes mellitus tends to increase, diabetes is not well controlled can cause oxidative stress. Oksidatf stress can increase ROS and antioxidants in our bodies may decrease, resulting in cell damage one pancreatic $\beta$ cells. To overcome the effects of free radicals on penderit DM and the possibility of complications that need an exogenous antioxidants include seaweed. The purpose of this study was to determine the effect of seaweed extract (Euchema SP.) Against pancreatic $\beta$ cell histology in wistar rats with alloxan-induced hyperglycemia. This research type experimental dalah Post Test Only Control Group Design conducted on 25 male rats aged 2-3 months ISTAR. Rats were divided into five kelompokyaitu 1 negative control group $(K N)$ were given a standard diet, the first group of positive control (KP) induced alloxan in Intra Peritoneal $150 \mathrm{mg} / \mathrm{kg}, 3$ Kelompom induced alloxan and given a seaweed extract (PI): 174mg / 200gr BB rats (P2): 352, $8 \mathrm{mg} /$ $200 \mathrm{~g} \mathrm{BB}$ rat, (P3): $529.2 \mathrm{mg} / 200 \mathrm{~g} \mathrm{BB}$ rats. The treatment was done for 48 days. Data were statistically processed using ANOVA test formula with a $95 \%$ confidence level. Results showed The average number of pancreatic $\beta$ cells in the negative control $(45.8 \pm 8.871)$, the group of the positive controls $(110 \pm 1581)$ on the treatment kelompk occurred increasing the number of pancreatic beta cells, PI (176.6 \pm 2.074$)$, $P 2(17.25 \pm 2.02) P 3(30.6 \pm 40.99)$. Annova test showed significant difference with $P$ Value 0.0005 Alpha $P \leq 0.05$. It is concluded that the extract of seaweed (Euchema $S P$.) On histological cell $\beta$ pancreas in rats Wistar hyperglycemia induced by alloxan, the results of this study can be applied in humans, especially people with diabetes because it has been tested, it extracts umput sea can repair cells pancreatic $\beta$ on the state of hyperglycemia
\end{abstract}

Keywords: Euchema Sp, pancreatic $\beta$ cells and hyperglycemiaPosy.

\section{A. Pendahuluan}

Pola penyakit di Indonesia mengalami pergeseran yang cukup meyakinkan sebagai dampak positif pembangunan yang dilaksanakan oleh pemerintahan. Perubahan pola penyakit itu diduga ada hubungannya dengan cara hidup dan pola makan yang berubah. Penyakit infeksi dan kekurangan gizi berangsur turun, penyakit menahun yang disebabkan oleh penyakit degeneratif, diantaranya diabetes mellitus meningkat dengan tajam. (Suyono , 2006). Diabetes Mellitus adalah suatu keadaan terjadinya peningkatan kadar glukosa plasma dari nilai normalnya yaitu $\geq 200 \mathrm{mg} / \mathrm{dl}$ pada pemeriksaan glukosa darah sewaktu atau $\geq 126 \mathrm{mg} / \mathrm{dl}$ pada saat puasa. Dalam membicarakan diabetes mellitus pasti tidak lepas dengan istilah hiperglikemia. Hiperglikemia disebabkan karena kelainan sekresi insulin, atau gangguan kerja dari insulin (Rand, et al, 2001: Johansen, et al, 2005).

Hiperglikemia pada diabetes melitus terlibat dalam pembentukan radikal bebas. Hiperglikemia menyebabkan autooksidasi glukosa, glikasi protein, dan aktivasi jalur metabolisme poliol yang selanjutnya mempercepat pembentukan senyawa oksigen reaktif. Pembentukan senyawa oksigen reaktif tersebut dapat meningkatkan modifikasi lipid, DNA, dan protein pada berbagai jaringan. Modifikasi molekuler pada berbagai

E-ISSN: 2657-0300 Lembaga Penelitian dan Penerbitan Hasil Penelitian Ensiklopedia $\quad 99$

P-ISSN: 2657-0319 
jaringan tersebut mengakibatkan ketidakseimbangan antara antioksidan protektif (pertahanan antioksidan) dan peningkatan produksi radikal bebas. Hal ini merupakan awal kerusakan oksidatif yang dikenal sebagai stres oksidatif. Dampak negatif pada membran sel akan terjadi reaksi rantai yang disebut peroksidasi lipid. (Purnomo ,2000).

Peningkatan kadar glukosa dalam darah disebabkan oleh kerusakan pankreas sehingga tidak dapat menghasilkan insulin. Kerusakan pankreas ini dapat disebabkan oleh senyawa radikal bebas yang merusak sel-sel pada pankreas sehingga tidak dapat berfungsi (Studiawan, 2004). Peningkatan radikal bebas secara umum menyebabkan gangguan fungsi sel dan kerusakan oksidatif pada membran. Pada kondisi tertentu antioksidan mempertahankan sistem perlindungan tubuh melalui efek penghambat pembentukan radikal bebas. Efisiensi mekanisme pertahanan tersebut mengalami perubahan pada diabetes mellitus. Penangkapan radikal bebas yang tidak efektif dapat menyebabkan kerusakan jaringan (Rajasekaran dkk, 2005: Kaleem dkk, 2006).

Meningkatnya kesadaran masyarakat terhadap kesehatan telah merubah pola makan masyarakat untuk cenderung memilih bahan pangan yang diyakini dapat membuat badan sehat. Rumput laut adalah salah satu bahan pangan yang diketahui kaya akan nutrisi esensial seperti enzim, asam nukleat, asam amino, mineral, serta berbagai macam vitamin sehingga banyak digunakan sebagai suplemen makanan dan kecantikan. Kandungan dietary fiber dan nutrisinya bermanfaat sebagai antioksidan, antimutagenic,anti koagulan, anti tumor, dan mempengaruhi metabolisme lipid. Rumput laut juga sebagai sumber iodium alami yang terbaik. ( Nindyaning, 2009: . Dhargalkal et al, 2005).

Rumput laut kaya berbagai nutrisi, salah satu yang menjadi sorotan adalah berbagai jenis vitamin dan mineral yang berperan sebagai antioksidan alami. Rumput laut banyak digunakan sebagai bahan makanan secara langsung karena mempunyai kandungan gizi yang cukup baik sehingga dapat menyehatkan. Zat gizi yang terkandung dalam Eucheuma sp antara lain, karbohidrat (39 - $51 \%)$, Protein (17,2 27,13\%), asam lemak esensial, mineral (K, Ca, P, Na, Fe, I), vitamin (A, B1, B2, B6, B12, C), dan berbagai enzim.(Astawan., 2009). Nutrisi yang optimal dalam rumput laut mampu memberikan fungsi imun terbaik, merevitalisasi tubuh, mendukung kesehatan jantung, memperbaiki pencernaan, menguatkan sistem saraf, dan menyeimbangkan hormon. Bahan pangan ini juga baik untuk menyehatkan rambut, memperkuat kuku dan gigi. (http://rumputlaut.org/artikel, 2009). Masih sedikit informasi tentang aktivitas rumput laut sebagi antioksidan. Antioksidan mempunyai peran yang penting dalam mencegah perjalanan penyakit degeneratif yang diakibatkan oleh gangguan atau ketidakmampuan sistem antioksidan tubuh dalam melawan radikal bebas. (Patra at al, 2008: Brambilla et al 2008: . Kim et al, 2008).

Untuk meredam kerusakan oksidatif tersebut diperlukan antioksidan (Bambang $\mathrm{S}$ dan Eko S, 2005). Antioksidan adalah senyawa yang dapat meredam dampak negatif oksidan (Purnomo, 2000. Dalam sel normal selalu terdapat keseimbangan antara produksi radikal bebas dan antioksidan. Dalam tubuh kita terdapat antioksidan alami yang terdiri dari antioksidan enzimatik seperti superoxide dismutase (SOD), katalase, glutathion peroksidase (GSH Px),dan gluthation reduktase (GR) serta antioksidan non enzimatik seperti vitamin A,E dan C,a lipoic acid, gluthation,trace element $(\mathrm{Cu}, \mathrm{Zn}, \mathrm{Se})$, coenzim $\mathrm{Q} 10$, serta beberapa cofactor seperti asam folat, uric acid, vitamin B1,B2,B6,B12. Antioksidan yang dihasilkan oleh tubuh sendiri akan melawan efek 
toksisitas dari radikal bebas. Namun pada beberapa keadaan seperti hiperglikemia, hipoxia, iskemi, dan kerusakan sel, produksi radikal bebas akan sangat meningkat dan antioksidan yang dihasilkan tubuh tidak mampu melawannya (Setyohadi et al, 2006). Pemberian antioksidan diperlukan pada pengobatan diabetes, karena obat antidiabetes tidak bekerja memperbaiki sel- $\beta$ pankreas yang rusak akibat radikal bebas, tetapi menstimulasi pelepasan insulin dari sel- $\beta$ pankreas (Adnyana et al , 2004), dan dapat mencegah komplikasi mikrovaskular dan makrovaskular (Soetedjo, 2009).

Para ilmuwan berusaha memperoleh sumber alternatif antioksidan yang berasal dari bahan alami, diantaranya rumput laut. Rumput laut banyak dimanfaatkan dalam dunia kedokteran dan farmasi antara lain sebagai bahan obat batuk,antihiperkolesterol, antibiotik dan sumber Iodium. Terdapat pula kandungan vitamin A, vitamin E, vitamin $\mathrm{C}$ dan selenium yang mempunyai efek antioksidan. (Johansen, et al, 2005: Pilona, et al, 2007). Eucheuma sp merupakan salah satu jenis rumput laut merah (Rhodophyceae) dan tergolong dalam divisio Thallophyta.( Atmadja, 2009). Jenis Eucheuma sp. tersebar luas di perairan pantai Indonesia dan sudah dibudidayakan secara intensif. (Astawan., 2009). Eucheuma sp merupakan salah satu kelompok rumput laut karaginofit, yaitu rumput laut yang mengandung bahan utama polisakarida karagenan. Karagenan adalah senyawa polisakarida yang tersusun dari unit -D-galaktosa dan ..-L-galaktosa (Astawan, 2009) anhidrogalaktosa yang dihubungkan oleh ikatan 1,4 glikosiklik dimana setiap unit galaktosa mengikat gugusan sulfat.8-12. Karagenan yang terkandung dalam Eucheuma sp. memiliki karakteristik jelly yang lembut dan elastis sehingga banyak dimanfaatkan dalam industri makanan, kosmetik dan farmasi. Karagenan dapat menurunkan keadaan glukosa di sirkulasi dengan cara mengahambat penyerapan glukosa di proksimal usus halus sehingga dapat mengurangi kadar glukosa post prandial. Efek penurunan kadar glukosa dari karagenan rumput laut sangat berguna untuk mencegah dan mengelola kondisi metabolik pada pasien diabetes melitus. (Panlasigui, et al, 2003: Dumelod, et al, 1999: Vaugelade ,2000).

Penelitian Nugroho dan Endang juga menyebutkan bahwa sediaan uji ekstrak Eucheuma sp. menimbulkan efek menurunkan kadar glukosa darah pada tikus wistar yang hiperglikemi (Nugroho, 2004, Nugroho 2006). Hal ini karena Eucheuma sp. mengandung senyawa karagenan yaitu salah satu jenis serat larut dalam air yang sukar dicerna oleh enzim pencernaan manusia. Eucheuma sp. mempunyai kandungan serat kasar karagenan sebanyak 65,75\% pada setiap 100 gram Eucheuma sp. kering. (Istini S, 2009). Untuk membuat tikus diabetes dilakukan dengan induksi aloksan. Aloksan $(2,4,5,5$ tetraoksipirimidin) adalah zat yang lazim digunakan untuk membuat tikus dan beberapa species hewan percobaan menjadi hiperglikemia selektif merusak sel $B$ pankreas yang memproduksi hormon insulin sehingga terjadi insulin dependen diabetes mellitus (disebut diabetes aloksan) yang identik dengan diabetes mellitus tipe 1 pada manusia.20,21 Sakurai et al, 2001: Devi et al, 2008). Sampai saat ini belum banyak penelitian mengenai khasiat antioksidan pada Eucheuma sp. yang dapat dijadikan sebagai alternatif obat alami bahari. Berdasarkan hal tersebut, maka peneliti berkeinginan untuk meneliti mengenai efek rumput laut Eucheuma $s p$ terhadap histologi sel $\beta$ tikus hiperglikemia yang induksi aloksan..

\section{B. Metodologi Penelitian}

Jenis penelitian ini adalah penelitian eksperimental dengan rancangan penelitian post test control group design. Sampel dari penelitian ini adalah tikus putih jantan sebanyak 35 ekor yang dipilih secara acak, berumur 4-5 bulan dengan berat badan E-ISSN: 2657-0300 Lembaga Penelitian dan Penerbitan Hasil Penelitian Ensiklopedia $\quad 101$ P-ISSN: 2657-0319 
berkisar 200-300 gram. dengan kondisi sehat (aktif dan tidak cacat). Sebelum perlakuan, 35 ekor tikus terlebih dahulu diaklimatisasi selama satu minggu. Pada hari ke-8 diukur kadar glukosa darah puasa. Tikus yang dipilih adalah tikus yang mempunyai kadar gula darah normal (50-135 mg/dl) ( Matruka, 1981: dan Loeb 1989 dalam Kusumawati, 2004). Pengukuran kadar glukosa darah dilakukan dengan menggunakan glucose meter (gluco-DR). Darah diambil dari ekor tikus. Bahan rumput laut segar diiris-iris dengan pisau, dihaluskan dengan blender. Kemudian dimaserasi dengan etanol $96 \%$ sampai semuanya terendam. Diaduk sekali-sekali dan dibiarkan selama 5 hari kemudian disarin. Perlakuan ini dilakukan secara berulang sebanyak tiga kali yang masing-masingnya selama 5 hari. Semua filtrat disatukan, kemudian didestilasi vakum dan hasil destilat dikentalkan dengan menggunakan rotary evaporator hingga diperoleh ekstrak kental (Nasir,SM,1998). Dalam penelitian ini menggunakan Aloksan $125 \mathrm{mg} / \mathrm{kgBB}$ secara Intraperitonel . Dosis Ekstrak rumput laut: $\mathrm{P} 1=4 \mathrm{gr} / \mathrm{kgBB} /$ hari, $\mathrm{P} 2=8 \mathrm{gr} / \mathrm{kgBB} / \mathrm{hari}, \mathrm{P} 3=12 \mathrm{gr} / \mathrm{kgBB} / \mathrm{hari}$, dosis berdasarkan hasil penelitian yang pernah dilakukan oleh Almira Zada, 2009. Penentuan berdasarkan dosis untuk manusia berat badan $70 \mathrm{~kg}$ dikonversikan kepada tikus berat badan 200 gr, mengunakan tabel konversi Laurence-Bacharach dengan faktor konversi 0,018.(Ghost, 1971 dalam Kusumawati, 2004). Penelitian menggunakan sampel 35 ekor tikus putih jantan yang dibagi dalam 5 kelompok, sehingga didapatkan jumlah sampel untuk tiap-tiap kelompok sebanyak 7 ekor. Tikus sebanyak 35 ekor tersebut diaklimasi di dalam laboratorium, diberi makanan dan minuman selama satu minggu secara ad libitum (hari ke-1 - hari ke-7). Pada hari ke-8 semua tikus kecuali pada kelompok kontrol negatif dibuat diabetik eksperimental dengan memberikan injeksi aloksan dosis $125 \mathrm{mg} / \mathrm{kgBB}$ secara intraperitoneal. sampai mencapai kondisi hiperglikemia Kondisi hiperglikemia ditentukan dengan pemeriksaan kadar glukosa darah pada hari ke 4, 8, 10, 15, setelah induksi aloksan), dari beberapa penelitian sebelumnya keadaan hiperglikemia pada tikus baru terjadi setelah hari ke 5 atau ke 6. Sebelum diambil darahnya tikus dipuasakan 16-18 jam. Pengukuran kadar glukosa darah pada hari ke -4 atau hari ke-8 dimaksudkan untuk mengetahui apakah kadar glukosa darah sudah naik. Pengambilan darah dilakukan pada pembuluh darah ekor tikus. Setelah diperoleh keadaan hiperglikemia pada tikus, kelompok selain kontrol negatif dan kontrol positif diberikan diet Eucheuma sp. dengan dosis yang berbeda pada tiap-tiap kelompok perlakuan (P1,P2,P3) tiap hari selama 21 hari, sedangkan kelompok kontrol hanya mendapat pakan standar. Setelah 48 mencit diterminasi dengan menggunakan ethe diambl pankreas dan diperiksa secara histologi. Data yang diperoleh diolah dengan program komputer SPSS 16 for Windows. Data tersebut diuji normalitasnya dengan uji Saphiro-Wilk. Jika didapatkan distribusi data yang normal, maka dilakukan uji beda menggunakan uji statistik parametrik Unpaired T Test. Sedangkan jika didapatkan distribusi data yang tidak normal, maka dilakukan uji statistik non parametrik Mann-Whitney. Data yang diperoleh dianalisis secara statistic dengan uji One Way Anova dengan derajat kepercayaan 95\%, Jika terdapat perbedaan bermakna antara ketiga kelompok perlakuan $(\mathrm{p}<0,05)$, maka dilanjut kan dengan Post Hoc Analysis. 


\section{Hasil dan Pembahasan}

1. Rata-rata Jumlah Sel $\beta$ Pankreas Tikus Putih Pada Lima Kelompok Penelitian Setelah Perlakuan.

\begin{tabular}{|c|c|c|c|c|c|}
\hline \multirow{2}{*}{ NO } & \multicolumn{5}{|c|}{ Jumlah Sel Beta Pankreas } \\
\cline { 2 - 6 } & KN & KP & P1 & P2 & P3 \\
\hline 1 & 53 & 9 & 16 & 16 & 30 \\
\hline 2 & 36 & 10 & 15 & 20 & 32 \\
\hline 3 & 37 & 12 & 19 & 14 & 24 \\
\hline 4 & 48 & 11 & 18 & 18 & 35 \\
\hline 5 & 55 & 13 & 20 & 19 & 32 \\
\hline Rata-rata & 45,8 & 11,00 & 17,6 & 17,25 & 30,6 \\
\hline SD & 8,871 & 1.581 & 2,074 & 2,02 & 40,99 \\
\hline
\end{tabular}

Nilai rata-rata (mean) jumlah sel beta pada kelompok KN $(45,8 \pm 8,871)$, ini digunakan sebagai nilai normal jumlah sel beta tikus putih. Pada kelompok KP diperoleh rata-rata jumlah sel beta $(11,00 \pm 1.581)$ Lebih rendah dari kelompok KN. Pada Kelompok perlakuan terjadi peningkatan rata- rata jumlah sel beta pankreas dibandingkan dengan kelompok KP. Pada P1 didapatkan rata-rata jumlah sel beta (17,6 $\pm 2,074), \mathrm{P} 2(17,25 \pm 2,02)$ dan P3 $(30,6 \pm 40,99)$. Dilihat dari peningkatan jumlah sel beta ternyata peningkatan tertinggi pada perlakuan P3 lalu P1 dan P2.

2. Hasil Uji Anova Jumlah Sel beta Pankreas Tikus Jantan Pada Lima Kelompok Penelitian Setelah Perlakuan.

ANOVA

Jumlah Sel Beta Pankreas

\begin{tabular}{|c|c|c|c|c|c|}
\hline & $\begin{array}{l}\text { Sum of } \\
\text { Squares }\end{array}$ & $\mathrm{df}$ & $\begin{array}{c}\text { Mean } \\
\text { Square }\end{array}$ & $\mathrm{F}$ & Sig. \\
\hline $\begin{array}{l}\text { Between } \\
\text { Groups }\end{array}$ & 3841,840 & 4 & 960,460 & 45,050 & , 000 \\
\hline Within Groups & 426,400 & 20 & 21,320 & & \\
\hline Total & 4268,240 & 24 & & & \\
\hline
\end{tabular}

Berdasarkan tabel diatas dapat bahwa nilai $p$ value $0,000<$ dari $p$ alpha 0,05 ini dapat disimpulkan bahwa terdapat perbedaan yang bermakna antara jumlah sel beta pancreas dengan kelima kelompok penelitian. 
Vol. 2 No.1 Februari 2020

\section{Hasil Uji Post Hoc Test Multiple Comparisons}

Multiple Comparisons

Dependent Variable: Jumlah Sel Beta Pankreas

Bonferroni

\begin{tabular}{|c|c|c|c|c|c|c|}
\hline \multirow[b]{2}{*}{ (I) Kelompok } & \multirow[b]{2}{*}{ (J) Kelompok } & \multirow{2}{*}{$\begin{array}{c}\text { Mean } \\
\text { Difference } \\
(1-J)\end{array}$} & \multirow[b]{2}{*}{ Std. Error } & \multirow[b]{2}{*}{ Sig. } & \multicolumn{2}{|c|}{ 95\% Confidence Interval } \\
\hline & & & & & Lower Bound & Upper Bound \\
\hline \multirow[t]{4}{*}{ Kontrol Negatif } & Kontrol Positif & $-34,800^{-}$ & 2,920 & .000 & $-44,01$ & $-25,59$ \\
\hline & $\mathrm{P} 1$ & $-6,600$ & 2,920 & .351 & $-15,81$ & 2,61 \\
\hline & $\mathrm{P} 2$ & $-6,600$ & 2,920 & .351 & $-15,81$ & 2,61 \\
\hline & $\mathrm{P} 3$ & $-19,600^{\circ}$ & 2,920 & .000 & $-28,81$ & $-10,39$ \\
\hline \multirow[t]{4}{*}{ Kontrol Positif } & Kontrol Negati & $34,800^{\circ}$ & 2,920 & .000 & 25,59 & 44,01 \\
\hline & P1 & $28,200^{\circ}$ & 2,920 & .000 & 18,99 & 37,41 \\
\hline & $\mathrm{P} 2$ & $28,200^{\circ}$ & 2,920 & .000 & 18,99 & 37,41 \\
\hline & $\mathrm{P} 3$ & $15,200^{*}$ & 2,920 & .000 & 5,99 & 24,41 \\
\hline \multirow[t]{4}{*}{$\mathrm{P} 1$} & Kontrol Negati & 6,600 & 2,920 & .351 & $-2,61$ & 15,81 \\
\hline & Kontrol Positif & $-28,200^{*}$ & 2,920 & .000 & $-37,41$ & $-18,99$ \\
\hline & $\mathrm{P} 2$ & .000 & 2,920 & 1,000 & $-9,21$ & 9,21 \\
\hline & $\mathrm{P} 3$ & $-13,000^{*}$ & 2,920 & .002 & $-22,21$ & $-3,79$ \\
\hline \multirow[t]{4}{*}{$\mathrm{P} 2$} & Kontrol Negati & 6,600 & 2,920 & .351 & $-2,61$ & 15,81 \\
\hline & Kontrol Positif & $-28,200^{-}$ & 2,920 &, 000 & $-37,41$ & $-18,99$ \\
\hline & $\mathrm{P} 1$ & .000 & 2,920 & 1,000 & $-9,21$ & 9,21 \\
\hline & $\mathrm{P} 3$ & $-13,000^{*}$ & 2,920 & .002 & $-22,21$ & $-3,79$ \\
\hline \multirow[t]{4}{*}{$\mathrm{P} 3$} & Kontrol Negati & $19,600^{\circ}$ & 2,920 & .000 & 10,39 & 28,81 \\
\hline & Kontrol Positif & $-15,200^{\circ}$ & 2,920 & .000 & $-24,41$ & $-5,99$ \\
\hline & $\mathrm{P} 1$ & $13,000^{*}$ & 2,920 & .002 & 3,79 & 22,21 \\
\hline & $\mathrm{P} 2$ & $13,000^{*}$ & 2,920 &, 002 & 3,79 & 22,21 \\
\hline
\end{tabular}

Berdasarkan Tabel diatas dapat dilihat bahwa ternyata kelompok yang hubungannya bermakna terdapat pada setian kelompok karena nilainya kecil dari p alpha 0,05. Selanjutnya dilakukan uji Non Parametrik (Npar Test ) Kruskal-Wallis Test dan MannWhitney Test yang dilakukan terhadap jumalh sel beta pancreas pada kelompok control dan perlakuan yang memperlihatkan hubungan yang bermakna.

\section{Pembahasan}

\section{Jumlah Sel Bata Pankreas}

Pemberian aloksan sebanyak $150 \mathrm{mg} / \mathrm{Kg}$ BB dapat membuat keadaan hiperglikemia pada Tikus Putih dan dapat membuat penurunan jumlah sel beta pankreas yang dapat dilihat dari nilai rata-rata pada KP yaitu $(11,00 \pm 1.581)$, nilai rata-rata pada $\mathrm{KN}$ adalah $(45,8 \pm 8,871)$ nilai ini dijadikan sebagai patokan nilai normal untuk jumlah sel beta pankreas pada tikus putih. Pemberian aloksan sebanyak $150 \mathrm{mg} / \mathrm{Kg}$ BB menyebabkan terjadinya hiperglikemia pada tikus putih sehingga menyebabkan kerusakan pada sel beta pankreas. Aloksan bereaksi dengan merusak subtansi didalam sel beta pankreas sehingga menyebabkan berkurangnya granulagranula pembawa insulin didalan sel beta pankreas, karena kerusakan sel beta pankreas maka insulin tidak terbentuk sehingga kadar glukosa darah meningkat. Hal ini seperti proses diabetes melitus tipe I pada manusia ( Watkins, 2008;mSuharmiati,2003).

Aloksan dalam darah akan berikatan dengan GLUT-2 ( pengangkut glukosa ) yang memfasilitasi masuknya aloksan ke dalam sitoplasma sel beta pankreas. Didalam sel beta pankreas aloksan menimbulkan depolarisasi berlebihan pada mitokondria, sebagai akibat pemasukan ion $\mathrm{Ca} 2+$ yang diikuti dengan penggunaan energi berlebihan sehingga menyebabkan terjadinya kekurangan energi dalam sel dan mengakibatkan krusakan sel beta pankreas (Walde,et al,2002 ). Aloksan meningkatkan pelepasan insulin dan protein dari sel beta pankreas tetapi tidak berpengaruh pada sekresi glucagon. Efek ini spesifik untuk sel beta pankreas sehingga aloksan dengan 
konsentrasi tinggi tidak berpengaruh terhadap jaringan lain. Aloksan mungkin mendesak efek diabetogenik oleh kerusakan membran sel beta dengan meningkatkan permeabilitas. Mendemonstrasikan adanya depolarisasi membran sel beta pankreas dengan pemberian aloksan Dean dan Matthew (1972).

Sel Beta yang ada pada pulau langerhens memproduksi hormon insulin yang berperan dalam menurunkan kadar glukosa darah ( Guyton, 1976). Berdasarkan tabel 5.1 pada kelompok perlakuan yang diinduksikan aloksan $150 \mathrm{mg} / \mathrm{Kg}$ BB dan diberi ekstrak Eucheuma $S p$ selama 48 hari didapatkan rata-ratapeningkatan jumalh sel beta pankreas P1 $(17,6 \pm 2,074), \mathrm{P} 2(17,25 \pm 2,02)$ dan P3 $(30,6 \pm 40,99)$ hasil ini lebih meningkat dibandingkan KP $(11,00 \pm 1.581)$. Dari uji statistik dapat disimpulkan ternyata ada perbedaan yang bermakna antara jumlah sel beta dengan lima kelompok penelitian dengan nilai $\mathrm{p}$ value $0,000<$ dari $\mathrm{p}$ alpha 0,05 . Analisis lebih lanjut dengan uji post hoc test membuktikan bahwa ada perbedaan yang bermakna antara kelompok kontrol positif, kontrol negatif dan perlakuan P1,P2 dan P3.Kelompok pada P3 yang paling tinggi peningkatan jumlah sel beta dibandingkan P1 dan P2. Hal ini menunjukan bahwa efek dari Eucheuma sp terhadap Sel beta pankreas ada dipengaruhi oleh dosis artinya diet eksrtak Eucheuma sp dengan tiga dosis yang bervariasi akan memberikan efek yang bermakna terhadap jumlah sel beta pankreas.Peningkatan jumlah sel beta pankreas pada kelompok perlakuan ini disebabkan pengaruh ekstrak Eucheuma sp yang berfungsi sebagai anti oksidan karena setiap 100 gram Eucheuma sp mengandung vitamin A sebanyak 82,59 IU, vitamin E sebanyak 0,87 mg, vitamin $\mathrm{C}$ sebanyak $43 \mathrm{mg}$, dan selenium sebanyak 0,5 mg (Aptitna, 2008).

Vitamin A terutama dalam bentuk provitamin A (beta carotene) merupakan antioksidan yang mempunyai peran dalam menangkap radikal bebas peroksi dalam jaringan pada tekanan parsial oksigen yang rendah. Karena bersifat efektif pada konsentrasi oksigen yang rendah, beta karoten melengkapi sifat antioksidan.(Rand at al, .2001: Johansen , 2005). Vitamin C dapat bertindak sebagai antioksidan umum yang larut air, dengan cara mereduksi tokoferol teroksidasi didalam membran sehingga membantu fungsi tokoferol sebagai pertahanan baris pertama dalam proses peroksidasi lipid.(Rand at al, .2001: Johansen , 2005). Selenium (Se) yang merupakan salah satu komponen integral dari glutation peroksidase, membentuk pertahanan baris kedua terhadap peroksida sebelum senyawa tersebut dapat merusak membran dan komponen sel lain, bersama dengan vitamin E. Dengan demikian tokoferol dan selenium bekerja sinergis dalam melawan peroksida lipid. (Mayes, 2003).

Fungsi vitamin E adalah pemutus rantai, penangkap radikal bebas didalam membran sel dan plasma lipoprotein dengan bereaksi terhadap radikal peroksida lipid. Kandungan vitamin dan antioksidan pada rumput laut dapat melawan radikal bebas dalam tubuh. Mekanisme kerja rumput laut sebagai antioksidan memiliki dua fungsi. Fungsi pertama merupakan fungsi utama dari antioksidan yaitu sebagai pemberi atom hidrogen. Antioksidan $(\mathrm{AH})$ yang mempunyai fungsi utama tersebut sering disebut sebagai antioksidan primer. Senyawa ini dapat memberikan atom hidrogen secara cepat ke radikal lipid. Fungsi kedua merupakan fungsi sekunder antioksidan, yaitu memperlambat laju autooksidasi dengan berbagai mekanisme diluar mekanisme pemutusan rantai autooksidasi dengan pengubahan radikal lipid ke bentuk lebih stabil sehingga sel beta terjadi perbaikan dilihat dari peningkatan jumlah sel beta. Berdasarkan penjelasan diatas dengan karagenan dan vitamin $A, E$ dan $C$ sebagai antioksidan yang terkandung dalam Eucheuma sp dapat meningkatnya jumlah sel beta pankreas tentu hormon insulin dapat dihasilkan sehingga gula darah dapat diatur keseimbangannya. 
Vol. 2 No.1 Februari 2020

\section{Penutup}

Tenyata terdapat kerusakan sel beta pankreas karena induksi aloksan dilihat dari terjadikan penurunan jumlah sel beta dibandingkan KN. Ekstrak rumput laut Eucheuma sp berpengaruh terhadap peningkatan jumlah Sel Beta Pankreas tikus putih hiperglikemia yang diinduksi aloksan

\section{Daftar Pustaka}

Suyono S. Diabetes melitus di Indonesia. Dalam: Sudoyo AW, Setiyohadi B, Alwi I, Simadibrata M, Setiati S, eds. Buku ajar ilmu penyakit dalam. Edisi IV. Jilid III. Jakarta: Pusat Penerbitan Ilmu Penyakit Dalam Fakultas Kedokteran Universitas Indonesia, 2006: 18526

Rowland, N.E. and Bellush, L.L., 1989, Diabetes Mellitus : Stress. Neurochemistry and Behavior, Neuroscience and Biobehavioral Reviews, 13 (4) : 199-206.

Atmaja WS. Apa rumput laut itu sebenarnya? Available from URL: http:/www.coremap.net/menu/artikel. Accessed April 2010

Astawan M. Agar-agar pencegah hipertensi dan diabetes. Available from URL: http://www.cyberman.cbn.net.id. Accessed January 25,2010

Suryohandono, P. 2000. Oksidan, Antioksidan, dan Radikal Bebas. Buku Naskah Lengkap Simposium Pengaruh Radikal Bebas Terhadap Penuaan dalam Rangka Lustrum IX FKUA 7 September 1955-2000

Szkudelski, T., 2001, The Mechanism Of Alloxan And Streptozotocin Action In B Cells Of The Rat Pancreas, Physiology Research, 50: 536-54.

Sakurai K, Katon M, Someno K, Fujimoto Y. Apoptosis and mitokondrial damage in INS-1 cells treated with alloxan. Biol Pharm Bull 2001; 24(8): 876-882.

Setyohadi B, Alwi I, Simadibrata M, Setiati S. Buku Ajar Ilmu Penyakit Dalam. Edisi IV. Jilid III. Jakarta: Pusat Penerbitan Departemen Ilmu Penyakit Dalam Fakultas Kedokteran Universitas Indonesia, 2006: 1857

Soewoto, 2001., Biokimia Experimen Laboratorium, Jakarta, Widya Medika.

Santoso J, Saryono. Penggunaan rebusan daging buah mahkota Phaleria Macrocarpa (Schff. Boerl) dan pengaruhnya terhadap penurunan glukosa darah tikus putih jantan yang diinduksi aloksan [Internet]. Availablefrom:www.info.stikesmuhgombong.ac.id/edisi2saryo.

Velde FV, Ruiter GA. Carrageenan [Internet]. [cited 2009 January 30]. Available from: http://www.wileyvch.de/books/biopoly/pdf_v06/bpol6009_245_250.pdf

Vaugelade P, Hoebler C, Bernard F, Guillon F, Lahaye M, Duee PH, et al. Non-starch polysaccharides extracted from seaweed can modulate intestinal absorption of glucose and insulin response in the pig. In: Reproduction Nutrition Development. 2000.

Walde, S.S., Dohle, C., Schott-Ohly, P., Gleichmann, H., 2002, Molecular target structures in alloxan-induced diabetes in mice, Life Sciences, 71, 1681-1694.

Wilson, G.L. and LeDoux, S.P., 1989, The Role of Chemical in The Etiology of Diabetes Mellitus, Toxicologic Pathology, 17 : $357-362$. 